
seat; it appeared to him as if he had a bad cold and could
not hear distinctly.

These wires appeared to prevent the voices rising and filling the cathedral. It seems very difficult to determine where to place the wires so as to produce a really grood effect; but that they have a very great effect far beyond what one would have supposed, a priori, is admitted by all who have taken an interest in the matter here. Several members of the congregation have remarked that they heard better in the cathedral now, without knowing the cause. We have used very thin wire; a stranger would not perceive it unless his attention were called to it. We hope to make some further experiments especially with regard to the transepts of the cathedral.

The inexpensive nature of the experiment and the important result likely to be obtained make this a matter of great import. arice, independently of the great interest it possesses in a scientific point of view.

I may add that when in Dublin I attended Divine service in St. Andrew's Church, and having officiated in the church at different times I am well aware of the difficulty of filling it in consequence of the echo, but the use of the wires appeared to have made a very great differcnce, as I heard most distinctly. It seemed to me, however, that a far greater number were used, than my experience in Cork would have led me to suppose were necessary.

I hope this subject will receive the attention which it deserves. J. J. Murphy, Esq. Robert S. GregG

\section{Fertilisation of the Wild Pansy}

THERE are two points in the structure of the heartsease (Viola tricclor) which are not mentioned in Mr. Bennett's interesting article on its ferialisation, but which, I think, deserve notice. The first of these is the lip of the stigma, which closes the en. trance to the spur and must be pushed back by an insect trying to reach the nectary, thereby bending down the head of the stigma, so as to sueep any pollen that may be adhering to those parts of the insect which come into contact with it into its receptacle; while, in withdrawing, the insect necessarily presses against the lower side of the lip, and raises up the whole stigma, thus rendering self-impregnation impossible, or at least highly improbable. Modifications of the same contrivance may be seen in many other flowers, e.g. Finsuicula, Iris, Sc.; it reaches, perhaps, its greatest perfection in Mimulus and Bignonia, $t$ where, to the usual mechanical disposition of the parts, there is added irritability of the stipmatic lobes, which close together spontaneously. when touched, expanding again after a while, if not already pollenated. $\neq$

The second point to which I have alluded is the close, hairy lining of the fore part of the spur, forming a narrow groove at the base of the lowest petal.§ This groove generally contains

* Both these points have already been described by Prof. Hildebrand ("Die Geschlechter-Vertheiluag bei den Pfianzen." p. 53). Unfortunately, I have not the works of Sprengel and Hermann Müler to refer to.

$t$ I have had no opportunity of examining the latter, but from the pub lished descriptions it seems to correspond in its main features with Mimulus, of the process of fertilisation of which a full account has been given by Mr. F. E. Kitchener in'the Fournal of Botany for April.

F. Whiten it becomes necescary to introduce a new word into the language it is always well to select the most appropriate that off rs itself. Some time ago Mr. A. W. Bennett wroce to the Fournal of Botany (vol. ix p. r12), ago Mr. A. W. Bennett wrote so thestions for a tetter rendering of the German word Bestinubung

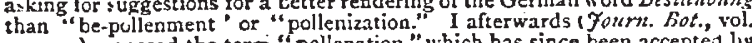
x, p. 25) proposed the tera "pollenation," which has since been accepted lyy Mr. Bennett. He, however, continues to use the verb to "pollenize." Now, if I might be allowed the space, I should like to state my reasons for objecting to this expressisn-(t) The root pollen is Latin, while the termination s $\zeta \omega$ is Greek. Of course, this objection is over-ruled by common usage, aud by itself would go for nothing. (z) The word "pollenize" does noc in its structure convey the idea intended. Bestizuten means to "sprinkle with dust," to "dust with pollen." The termination "ize." on the other hand, gives the signification of change or conversion: thus to "pollenize" u.ould naturally mean to "pulverize," to "turn to flour or pollen," and might be correctly applied to the processes going on in the substance of the anthers, but not, witr out violence to grammar, to the application of pollen to the stigma. Nume ous precederits might be cited for the use of the word "pullen," unaltered, as a verb, from which would be derivable either "pollenation" or "pollenment," but this would be at the risk of offence to ears scientific. The same objection would apply with still greater force to the word "be.pollen." "Empollen" is more euphonious, but would conrey a slightly different meaning. On the whole, the word that I have used classical readers might give us their opinions.

Morphologically speaking, this is the uppermost petal, which, by the bending of the peduncle and consequent inversion of the flower, is made to assume the position best fitted to afford a convenient landing-place for insects. a quantity of pollen that has fallen from the overhanging anthers. There is also a small tuft of hairs at the base of each of the lateral petals, arching over the essential organs, and forcing an insect to approach the nectary from below. Tbese lateral tufts are present, I believe, in all the violets, but $V$. tricolor (includ. ing therein several sub-species) is the only British species which has the spur lined with hairs, as well as the only one not known to bear self-fertile cleistogenous flowers.

Although the flowers of the wild heartsease are quite scentless to our blunt organs, does it follow that they are necessarily so to an insect's far more delicate sense?* Some of the cultivated pansies are very sweet, and I am not aware that this quality has ever been made an object for selection by florists. These large garden pansies are much frequented by Bombus muscorum, which may be watched while performing the act of pollenation, as described by Prof. Hildebrand.

W. E. HART

Kilderry, Co. Donegal

P.S.-Mr. Farrer, in writing of Lotus corniculatus (NATURE, vol. vi. p. 499), says :- "Five of the stamens, viz., those of the inner whorl, are shorter than the others, and their filaments are dilated at the top." Here Mr. Farrer's usually accurate pen seems somehow to have mnde a slip. It is the long outer sta. mens, those opposite the calyx-teeth, which have their filaments thus curiously modified for the purpose there explained.

\section{Fertilisation of Orchids}

MR. DARWIN, in his "Fertilisation of Orchids," speaks of a Madagascar orchid (Angracum sesquipedale) with nectaries 11 ? inches long, and supposes that these plants must be ferilised by the efforts of huge inoths, with protosces capable of such expansion, to obtain the last drops of the nectar which is secreted in the lower part of these whip-like nectaries. Can any of your readers tell me whether moths of such a size are known to in. habit Madagascar? They would probably be Sphingida of some kind, as no other moths would combine sufficient size and length of proboscis.

Culverlea, Winchester, June 2

\section{Ground Ivy}

I HAVE this spring found, in many different places, specimens of ground ivy, having flowers with undeveloped stamens. They seem generally, though not always, to be on different plants from those bearing perfect flowers, and below the average in size, the tube being more s!ender. Also, in nearly all my specimens, the stigmas diverge in a more or less horizontal direction (across the flower) instead of remaining open in the usual vertical one. Is this second form of the flower common? and if so, may not the greater tendency to horizontal divergence compen. sate for the want of stamens, by bringing the stigmas into the position most favourable for receiving from an insect any pollen which a previous visit to a perfect flower may have left on its head or back?

S. S. D.

\section{Hail Storm}

During the passage across us this afternoon of a thunderstorm moving at so great a distance above the earth that the thunder was very feeble and the lightning very faint, we had a great hail storm, which commenced with conical-shaped opaque stones of the size of peas, at $4^{\mathrm{h}} 27^{\mathrm{m}}$ (only lasting one minute), beginning again at $4^{\mathrm{h}} 29^{\text {tar }}$ with circular transparent stones having a small opaque nucleus (again only lasting one minute), followed at $4^{\mathrm{h}} 33^{\mathrm{m}}$ with flattened stones of the form of common acid drops, transparent, except a thin opaque envelope (which soon melted), and having externally in the centre a small rugged piece of ice. The size varied from two to three inches in circumference, and the force with which they fell cut of the leaves from the trees and broke 200 panes of glass in my greenhouses. These stones con. tinued to fall for seven minutes with very heavy rain.

Twelve hailstones were gathered after the storm was over, and on being melted yielded 0.060 inch of water when measured in the glass of an eight-inch gauge, and the amount caught within an eight-inch hoop measured 0.750 of an inch, and this added to the rain, gave 1430 inches as the amount fallen during the storm.

Highfield House Observ., Nottingham, June 3

E. J. LOWE

* The flowers of $V$. palustris, which are nearly unicolorous with a fer dark lines pointing to the nectary, are apparently scentless; but after standing for a short time in water in a warm room, they become quite sweet. 